\title{
A mirror of the times
}

Beyond the Hippocratic Oath: A memoir on the rise of modern medical ethics

John Dossetor

University of Alberta Press; 2005

268 pp \$39.95 ISBN o-88864-453-1

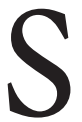

itting beside fellow writer John Gregory Dunne at the funeral of a common friend, Gore Vidal leaned over and asked Dunne, "Are you working?" Vidal could have anticipated the answer. Writers are almost always working: observing, considering, interpreting, remembering - all in an attempt to ultimately create something useful for a reader. When the writer is particularly thoughtful, with something especially interesting to say, an edifying book results, like Dr. John Dossetor's Beyond the Hippocratic Oath: A memoir on the rise of modern medical ethics.

The title of the book understates its content, much broader than a memoir revolving solely around the theme of medical ethics. The book has 3 themes, in fact: the course of Dossetor's long medical career, a history of the evolutionary changes in medicine during that time, and the development of medical ethics in response to those changes, "weaving a web of values en route." If at least 2 of the themes are of interest, this book may be for you.

The author's memories from a ca$m$ reer now in its seventh decade are vivid; and, because of the ground they cover, worth spending time with. Dossetor was on the forefront of the treatment of endocarditis and complex liver disease, and played seminal and leadership roles in the fields of nephrology, renal

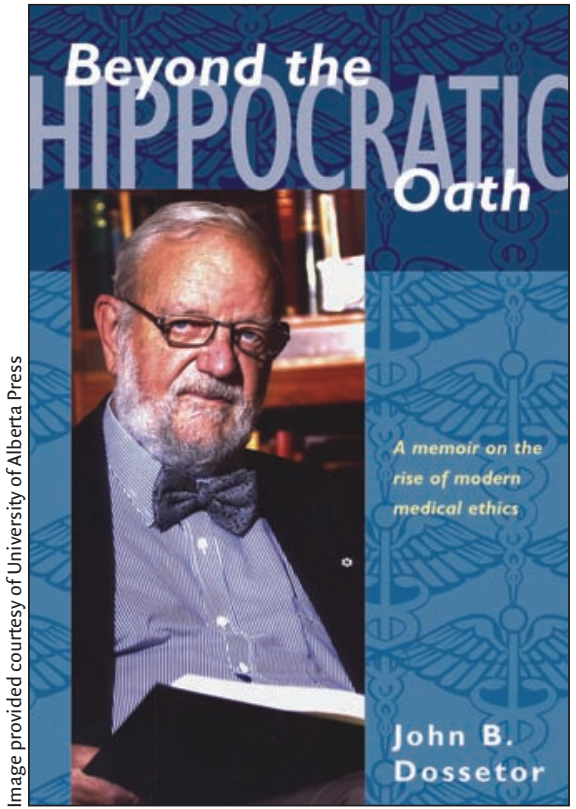

transplantation and transplantation immunology. Provoked all along by questions about the ethical implications of things he saw or did, at the age of 60 he decided to leave his established work to acquire expertise in bioethics. Stories and clinical cases in the book taken from those broad experiences are memorable. A chilling example is the inclusion, in a discussion of research ethics, of the erudite and sensitive document, "Guidelines for New Therapy and Human Experimentation," adopted by German physicians in I93I, which was subsequently ignored during the Nazi era. "It is a warning to us all," Dossetor cautions.

The book's stories serve as a mirror of the times. The field of medical ethics early in Dossetor's career, for example, was more like medical etiquette, the elements of which were simple: concern for the doctor-patient relationship, and especially for not doing harm. Beyond these, how physicians behaved was largely dependent on what they as apprentices had learned from their mentors, all of which reflected a pervasive base of paternalism. Showing up in a neighbourhood of London during his obstetrics rotation as a medical student, for example, knowing approximately nothing about how to deliver a baby, the young Dossetor did so under the move-by-move guidance of an experienced midwife. "Give that a firm hand." "That's it, clamp it just about there but milk some blood out of the cord before you do." After the successful delivery, the grandmother who had kept a background but watchful eye on the proceedings, took the novice doctor aside and said, "It was so good to have you here, doctor; we know that nurse is very good, but it's good to have the doctor here as well."

Included in the book, too, are frank admissions of personal and systemic failures along the way. "The reader will find it hard to condone our passivity, and indeed, so do I." Dossetor writes of a time when he and another young physician on a troop ship failed to report the alcohol-impaired ship's surgeon to medical command, tacitly leaving discipline up to the discretion of the ship's captain. "I like to think that I gained some integrity in such matters later on," Dossetor continues. Subsequent anecdotes confirm that he did. Among them are his resigning a paid consultancy with a medical device company when a potential ethical conflict surfaced, and his declining research training opportunities in Texas and North Carolina dur- 
ing a period when racism would have affected the care of people who would be his patients or research subjects.

The book is not without limitations. The manner in which substantial sidebars are incorporated with the text, for example, is distracting. The sidebars are interesting tables and lists demonstrating how the topic being discussed relates to the history of medicine or to ethical issues. However, there is usually no indication in the narrative about the best time for the reader to direct attention to the sidebar. It is common to find oneself ready to turn the page, only to remember that the insert has not been reviewed. This not only interrupts the train of thought to which the narrative has led, but also diminishes the impact of the sidebar, since it is often out of phase with the text that has just been read.

Occasionally, too, the author gets too detailed or technical for most readers. The extensive description of HLA-typing, for example, makes one impatient to get to the more interesting aspects of the story, a trip to study specific HLAtype Inuit families in the Arctic, and the ethical dilemma posed by getting communal consent from the community elders to do so rather than individual consent from the research subjects.

These limitations are minor deviations, however. Mostly, the writing progresses interestingly, weaving the book's themes in a way that carries the narrative along, and allows us to get to know the author somewhat as a person as well. In fact, getting to know the author even partially is one of the inspiring elements of the book - not only because of who it reveals Dossetor to be, but as an example of something bigger - an example of what an inquisitive individual with broad interests, sensitivity and drive can accomplish.

\section{Lawrence J. Hergott}

Associate professor of medicine University of Colorado Health Sciences Centre Denver, Colo.

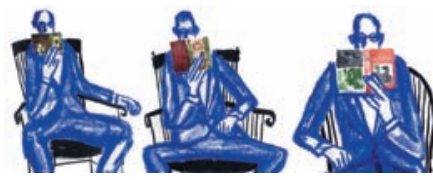

\section{Room for a view}

\section{It's not all about the brain}

$\mathrm{S}$ ome time ago I read "Lowell's Command," an essay on Robert Lowell by Seamus Heaney. ${ }^{1}$ In it, Heaney wrote: "In spite of the cruel cycles of mania, maybe even because of them, Lowell wrote extraordinarily and achieved eminence." This seemed to me to be the final word on the subject of mental illness and creativity essentially, who can know which is which, if the mental illness stole, or if it bequeathed? After reading this I imagined any biography that wished to split that hair could always be plausibly assaulted from either side of the argument; perhaps it was best, resignedly, to recognize accomplishment both as "in spite of" and "because of" and leave it at that.

The recently published book Lincoln's Melancholy, ${ }^{2}$ by Joshua Wolf Shenk, takes up this challenge. The book is very much an examination of the range and toll that depression manifested in the American president's life. Qua Heaney, Shenk is mostly - but not always - a cheerleader, a member with reservations in the "because of" camp. Along these lines Shenk writes, "A person with a melancholy temperament had been fated with both an awful burden and what Byron called a 'fearful gift.' The burden was a sadness and despair that could tip into a state of disease. But the gift was a capacity of depth, wisdom - even genius." But, but ... it's that very big but that this book attempts to make the case for. Shenk puts it thus: "Lincoln didn't do great work because he solved the problem of his melancholy. The problem of his melancholy was all the more fuel for the fire of his great work." So in Lincoln's melancholy we are given, to a small degree, a mental hagiography.

Well, on to my objections to this $\infty$ book. Stated outright on the dust : jacket, Shenk has a personal investment in the topic, a potential bias: "With empathy and authority gained ڤ̊ from his own experience with depression, Shenk crafts a nuanced, revelatory ¿ account of Lincoln and his legacy."
Wait a minute. Alarm bells begin to sound. Would it be fair, then, to interpret this book through the empathy and authority I've gained through my own mental illness, if I had one? That would be an unfair injection of my own experience into the review; so is Lincoln's Melancholy a potentially unfair personalization of a text that should, as much as possible, struggle for objectivity. I say potentially because Shenk is far too scrupulous a historian and writer to let his own life become a sideshow; his life does not intrude on the life of his subject. It is the dust jacket writers who should be censured.

Another immediate concern loomed for me as I read this book, a philosophical one: looking through the prism of mental illness, Shenk with the best of possible intentions reduces a great man to a case study. To my mind, somehow, in the final analysis, this is a reductive process. Surely Lincoln the man is more than just Lincoln the melancholic? Perhaps I am being too critical, wanting the book to be something it isn't, for its stated aim is “... to see what we can learn about Lincoln by looking at him through the lens of his melancholy, and to see what we can learn about melancholy by looking at it in light of Lincoln's experience." To this end one whole section of the book attempts to determine if Lincoln suffered "clinical depression" of "the diagnostic categories of modern psychiatry." I fear here that, with the best of intentions, the - historically speaking - rather modern DSM-IV as well as current psychological concepts have been thrown at Lincoln's life, contemporaneously reinterpreting him as a depressive. This sort of thing is done all the time, and it seems to be a phenomenon that ultimately ends up diminishing its subjects; something is lost in the intense magnification upon one aspect of a personality. All the world is not a hospital! Though Shenk takes pains to mention that Lincoln is more than a diagnosis, more than a list of symptoms, ultimately the book's real quarry is the diagnosis and the boon it proved to his life. 